\section{Comparative Responses of Preharvest GA-treated Grapefruit to Vapor Heat and Hot Water Treatment}

\author{
W.R. Miller and R.E. McDonald \\ U.S. Department of Agriculture, Agricultural Research Service, U.S. \\ Horticultural Research Laboratory, 2120 Camden Road, Orlando, FL 32803
}

Additional index words. Citrus paradisi, quarantine treatment, market quality, postharvest handling, heat treatment, methyl bromide alternative

\begin{abstract}
Marsh' grapefruit (Citrus paradisi Macf.) produced in Florida must be certified for security against unwanted pests before entry into some domestic and export markets. Application of heat by hot water (HW) has been shown to cause severe injury to grapefruit; however, direct comparisons between forced vapor heat $(\mathrm{VH})$ and $\mathrm{HW}$ have been lacking. Grapefruit preharvest-treated with gibberellic acid (GA) or not treated, were postharvesttreated with VH or HW such that the surfaces of fruit were exposed to the same rate of temperature increases and treatment durations. Condition and quality attributes were then compared with ambient air (AA) and ambient water (AW) controls after storage. After 4 weeks' storage at $10^{\circ} \mathrm{C}$ plus 1 week at $20^{\circ} \mathrm{C}$, scald affected $5 \%$ of $\mathrm{HW}$ and $20 \%$ of VH-treated fruit. No scald developed on control fruit. At the end of storage, mass loss for $\mathrm{HW}$ and $\mathrm{VH}$ fruit was $\approx 5 \%$. HW-treated fruit had a 5-fold higher incidence of aging than VH fruit; however, control fruit showed significantly more aging than all heat-treated fruit. Gibberellic acid (GA) and the heat treatments reduced decay relative to the control. GA-treated fruit remained greener during storage than control fruit. These findings indicate that VH and HW treatments at the temperatures and durations to control the Caribbean fruit fly (Anastrepha suspensa, Loew) will likely cause peel injury to 'Marsh' grapefruit produced in Florida, regardless of treatment with GA.
\end{abstract}

Grapefruit produced in Florida must be subjected to an approved quarantine treatment for security against infestations of Caribbean fruit fly $(\mathrm{CFF})$. Approved quarantine treatments for grapefruit include fumigation with methyl bromide (MB), cold (Hallman and Chalot 1993), and harvesting fruit from flyfree groves (State of Florida Caribbean Fruit Fly Protocol)(U.S. Dept. of Agriculture, 1994). Most grapefruit shipped from Florida to markets requiring quarantine certification is harvested from designated fly-free zones. $\mathrm{MB}$ is scheduled to be phased out in the United States by the year 2001 .

Heat treatments are used for quarantine security against insects of fresh citrus (U.S. Dept. of Agriculture, 1994). Heated forced air is approved against Anastrepha spp. for grapefruit imported into the United States from Mexico, and static vapor heat $(\mathrm{VH})$ is approved for similar insects for grapefruit from Mexico (U.S. Dept. of Agriculture, 1994). Considerable research has been conducted on the effect of VH (Brown et al., 1991; Hallman et al., 1990; Miller et al., 1991), and hot water

\footnotetext{
Received for publication 27 June 1996. Accepted for publication 25 Nov. 1996. Mention of a trademark, warranty, proprietary product, or vendor does not constitute a guarantee by the U.S. Dept. of Agriculture and does not imply its approval to the exclusion of other products or vendors that may also be suitable. The cost of publishing this paper was defrayed in part by the payment of page charges. Under postal regulations, this paper therefore must be hereby marked advertisement solely to indicate this fact.
}

break. Fruit were harvested from control trees located just beyond wind drift of the same grove. GA-treated and control fruit were each harvested from three tree plots within the same grove. Fruit samples were replicated on the tree plots for each of three harvests. Fruit were picked randomly from tree canopies and ranged 9 to $10 \mathrm{~cm}$ in diameter. Fruit were not degreened, but were washed on a commercial brush bed-washer with Moldstrip 25 (Fresh Mark, Orlando, Fla.). VH treatment commenced $\approx 24 \mathrm{~h}$ after harvest. HW and ambient water (AW) treatments were conducted $48 \mathrm{~h}$ after harvest, and ambient air (AA) control fruit were held at room temperature $\left[\approx 20^{\circ} \mathrm{C}\right.$; relative humidity $(\mathrm{RH}) 90 \pm 5 \%$ ] until all treatments were completed.

$V H$ treatment. Sixty-six GA and control fruit each were placed into two separate plastic containers sized $(56.5 \times 36.5 \times 27.3 \mathrm{~cm}, \mathrm{~L} \times \mathrm{W}$ $\times \mathrm{H}$ ), to hold fruit during treatment. In each container, 45 fruit were inspected before $\mathrm{VH}$ treatment, and peel color CIE (1976) L*, a*, $\mathrm{b}^{*}$ (model CR-200 with an 8-mm aperture sensor; Minolta Chromameter, Osaka, Japan) with chroma $\left[\mathrm{C}^{*}=\left(\mathrm{a}^{* 2}+\mathrm{b}^{* 2}\right)^{1 / 2}\right]$ and hue angle $\left(h^{\circ}=\right.$ arctangent of $\left.b^{*} / a^{*}\right)$ values, and fresh mass were determined on 15 of these fruit. A five-fruit sample of GA and control fruit was used for determining volume displacement of fruit before and after treatment, after waxing and after 1 week of storage at $10^{\circ} \mathrm{C}$ to assess peel puffiness from possible water absorption. Remaining filler fruit (filled to complement of 66) were discarded after treatment. Three type T (copper-constantan, AGW 32, $0.2019 \mathrm{~mm}$ in diameter) thermocouples were inserted into each of three individual fruit in each of the two containers; one was inserted to the center core ( $40 \mathrm{~mm}$ into the fruit perpendicular to the equatorial surface); another was inserted just under the cuticle; and the third was positioned to record temperature $5 \mathrm{~mm}$ above the fruit surface. The two containers of fruit were arranged into the VH facility for treatment as described by Gaffney and Armstrong, (1990). Air flow within the chamber was maintained at $0.4 \mathrm{~m}^{3} \cdot \mathrm{min}^{-1}$; and $100 \% \mathrm{RH}$ maintained free moisture on the fruit surface during treatment.

$H W$ treatment. Fruit were placed into plastic containers as those used for the VH treatment. The hot water bath facility (Gaffney Engineering Co., Gainesville, Fla.) was a computer-controlled, self-contained system with two hot water bath reservoirs. Three thermocouples were placed in a single fruit located in the center of the fruit mass (middle layer of fruit) within each container. Thermocouples were positioned as described in VH-treated fruit, and the entry was sealed with hot glue to prevent water seepage into the fruit. The temperature of the water bath was maintained identical to the surface time/temperature profile obtained from the VH treatment. Hence, the surface temperatures to which $\mathrm{HW}$-treated fruit were exposed to were similar to the time/temperature profile for the VH-treated fruit.

$A W$ and $A A$ controls. Ambient water controls were immersed in tanks of water $\left(\approx 20^{\circ} \mathrm{C}\right)$ for the same duration of time as required for 


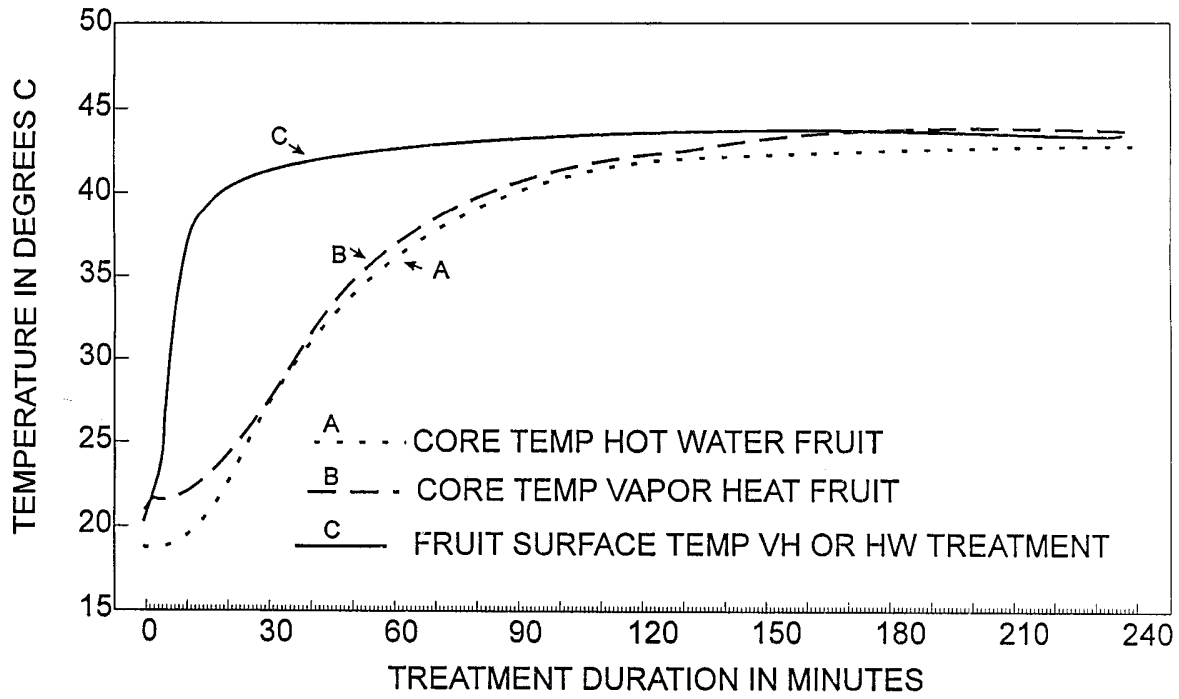

Fig. 1. Typical temperature/time profile of grapefruit surface during vapor heat and hot water treatments, and grapefruit core temperatures by treatment.

the $\mathrm{VH}$ or $\mathrm{HW}$ treatments. In addition, 50 fruit were held in ambient air $\left(20^{\circ} \mathrm{C}, 50 \% \mathrm{RH}\right)$ until all other postharvest treatments were completed.

Posttreatment storage and inspection. All fruit were treated with thiabendozole (TBZ) $\left(1000 \mathrm{mg} \cdot \mathrm{L}^{-1}\right)$ applied in an aqueous spray followed by waxing with Flavorseal 93 (FMC Corp., Lakeland, Fla.) after heat treatment. Forty-five fruit of each treatment were packed, 15 each, into $0.14-\mathrm{m}^{3}$ commercial, full-telescoping fiberboard boxes. Fruit were inspected after 1,2 , and 4 weeks at $10^{\circ} \mathrm{C}$, plus 1 additional week at $20^{\circ} \mathrm{C}$. At each inspection, fruit were rated for peel condition and quality attributes were determined. Peel pitting, aging (development of necrotic tissue at the stem end, also known as postharvest stem-end rind breakdown), scald, and general appearance of peel and calyx were subjectively rated (Miller and McDonald, 1991). Objective fruit color was measured on five fruit per box with the Minolta chroma meter. Fruit mass was recorded on five fruit per box after each inspection. The number of decayed fruit was recorded per box, and rotted fruit were removed and decay was identified by visible symptoms.

Total soluble solids (TSS), titratable acid- ity (TA), and $\mathrm{pH}$ were determined on 15 fruit after harvest and from 15 fruit per treatment after the final storage period. Objective firmness (model 1132; Instron Food Testing System, Canton, Mass.) was determined after 5 weeks of storage on 15 fruit per treatment, using a 9-cm-diameter flat anvil moving at 5 $\mathrm{cm} \cdot \mathrm{min}^{-1}$ to achieve a $5-\mathrm{mm}$ compression. After the final storage duration, comparative sensory evaluations of pulp and juice flavor, and of mastication texture were rated by at least seven informally trained panelists using a modified hedonic scale of 1 (poor) to 100 (extremely good).

Five fruit from each treatment were designated for determining fruit volume. These fruit were waxed after prestorage treatment. Each fruit was weighed and the volume determined by water displacement before treatment, after treatment, after waxing, and after 7 d of storage at $10^{\circ} \mathrm{C}$.

A complete factorial combination of treatments included +/-GA and heat treatments of $\mathrm{VH}, \mathrm{HW}, \mathrm{AW}$, and AA. Data were averaged over fruit and subjected to analysis of variance procedures for mean comparisons of the main factors of GA and treatments (AA, AW, VH, HW), and their interactions.

\section{Results}

Air temperatures within the $\mathrm{VH}$ chamber increased gradually from $20^{\circ} \mathrm{C}$ at the start, reaching $43.5 \pm 0.2{ }^{\circ} \mathrm{C}$ after $95 \mathrm{~min}$ and remaining near constant until the end of treatment. Fruit surface temperatures reached the target of $43.5^{\circ} \mathrm{C}$ in $\approx 95 \mathrm{~min}$ (range 90 to 100 min) (Fig. 1C). The core temperature of VH-treated fruit reached the target of $43.5^{\circ} \mathrm{C}$ after $\approx 170 \mathrm{~min}$ (range 165 to $175 \mathrm{~min}$ ) (Fig. $1 \mathrm{~B}$ ), whereas the core temperature of the HW-treated fruit reached $43^{\circ} \mathrm{C}$ after $\approx 185 \mathrm{~min}$ then increased to and remained at $43.2^{\circ} \mathrm{C}$ until the end ( $240 \mathrm{~min}$ ) of the HW treatment (Fig. 1A). The surfaces of fruit during the $\mathrm{VH}$ and HW treatments for each of the three harvests reached similar target temperatures of $\approx 43.5$ ${ }^{\circ} \mathrm{C}$. The initial pulp temperature of VH-treated fruit was slightly higher than the initial temperature of $\mathrm{HW}$-treated fruit before treatment because HW-treated fruit remained in an ambient treatment room $\approx 24 \mathrm{~h}$ longer than $\mathrm{VH}$ fruit before treatment.

At the end of storage, AA fruit had the highest and VH-treated fruit the lowest incidence of aging (Table 1). GA had no effect on aging. Peel scald affected $20 \%$ and $5 \%$ of VHand HW-treated fruit, respectively, and most scald on VH and HW fruit was severe. Scald did not develop on AW or AA fruit, and GA had no influence on scald development. Peel pitting was absent on all fruit following storage. There was significantly $(P \leq 0.05)$ less decay in GA-treated fruit compared with control fruit. There was less decay in VH- and HW-treated fruit than in AA or AW control fruit. About $97 \%$ of fruit rot was caused by stem end rots; mostly Phomopsis citri Fawc. and, to lesser extent, Diplodia natalensis, P. Evans. The remaining 3\% of fruit rot was caused by green mold (Penicillium digitatum, Sacc.). There was slight, but significantly less mass loss by AW than by fruit of all other treatments by the end of storage.

At harvest, values for peel color were significantly higher and less green for control than for GA-treated fruit; $L^{*}$ values were 80 and 78 , and $a^{*}$ values were -6.2 and -7.0 , (hue $=96.5,97.4$; chroma $=55.0,54.6$ ), respectively. Peel color differences persisted throughout storage, and at the final inspection

Table 1. Percentage of grapefruit, preharvest sprayed or not sprayed with gibberellic acid (GA), with symptoms of aging, scald, decay, and percent mass loss after ambient air (AA), ambient water (AW), vapor heat (VH), or hot water (HW) treatment and storage for 4 weeks at $10^{\circ} \mathrm{C}$ plus 1 additional week at $20^{\circ} \mathrm{C}$.

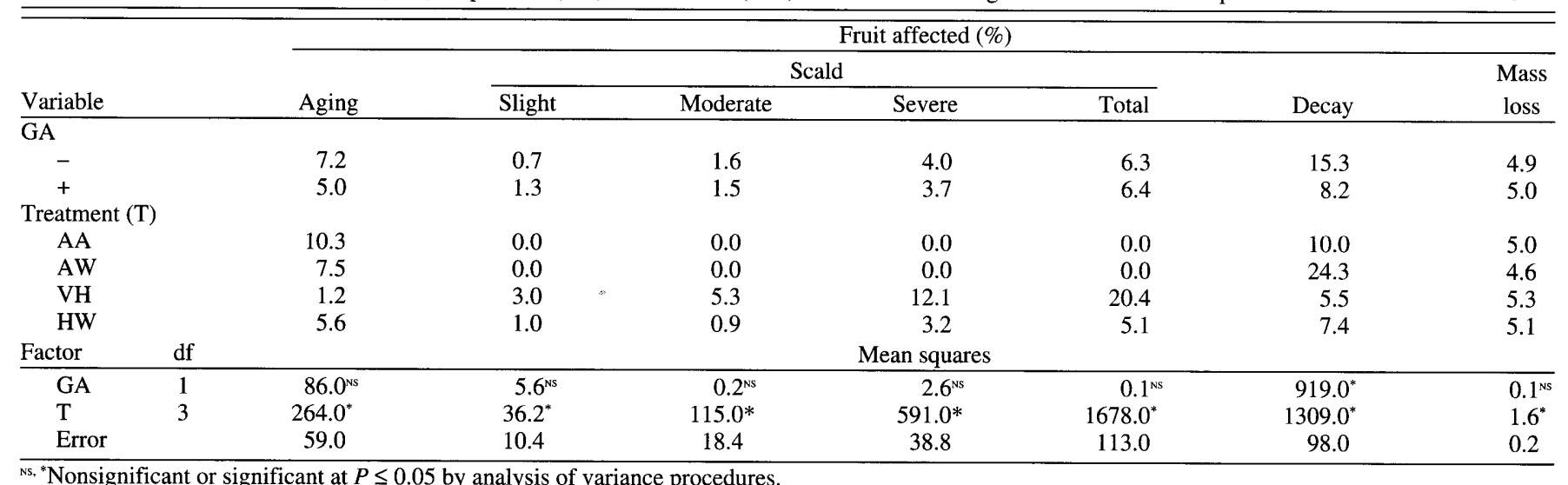


GA-treated fruit were greener and lighter in color than control fruit (Table 2). VH- and $\mathrm{HW}$-treated fruit were yellower than AA or $\mathrm{AW}$ fruit at the final inspection. Thus, fruit subjected to the heat treatments was yellower than controls, and there were no treatment differences in $b^{*}$ values after similar storage durations.

Means for TSS and TA were $8 \%$ and $0.8 \%$, respectively, at 5 weeks of storage and were not influenced by GA or heat treatments. Mean preference values for juice or pulp flavor were $\approx 77$ and 76 , respectively, at the final inspection, and they were not influenced by treatments. However, pulp texture of HW-treated fruit was significantly less preferred than that of all other treatments (Table 2). The significant GA $\times$ treatment interaction for pulp texture values was due to relatively high preference scores (81) for control, $\mathrm{VH}$, and $\mathrm{AW}$ fruit compared to scores of 71 and 73 for HW and AA fruit, respectively. Treatment texture scores for GA-treated fruit were more scattered, ranging from 74 to 78 , and were not affected by GA. Objective firmness at harvest was $\approx 31 \mathrm{~N}$ with no difference between control and GAtreated fruit; at the final inspection, mean firmness was $23.3 \mathrm{~N}$ with no difference among treatments.

After 1 week of storage at $10^{\circ} \mathrm{C}$, the volumetric displacement of AA control fruit was significantly less $(3.5 \%)$ than for $\mathrm{VH}-$ $(2.0 \%), \mathrm{HW}-(2.1 \%)$, or AW- $(2.3 \%)$ treated fruit. There was no affect of GA on volumetric displacement of fruit during similar storage (data not shown).

\section{Discussion}

HW-treated fruit failed to reach the target core temperature of $43.5^{\circ} \mathrm{C}$ during treatment in all three tests, possibly, at least in part, because of the slight difference in initial temperature of $\mathrm{VH}$ and $\mathrm{HW}$ fruit. The objective of exposing the surface of grapefruit to similar ment was, however, achieved (Fig. 1, line C). Previously, when we exposed grapefruit to only $\mathrm{HW}$, fruit were placed directly into $45^{\circ} \mathrm{C}$ water for $4 \mathrm{~h}$; then, core temperatures reached temperatures during either $\mathrm{HW}$ or $\mathrm{VH}$ treat-

$43.5^{\circ} \mathrm{C}$ after $2.25 \mathrm{~h}$, but after 5 weeks' storage, $57 \%$ of the HW fruit were rotted compared with 6\% for control fruit (Miller et al., 1988).

Both VH and $\mathrm{HW}$ reduced the incidence of decay. These findings are consistent with those of Brown et al. (1991), who reported that VH treatment at $43.5{ }^{\circ} \mathrm{C}$ for $4.5 \mathrm{~h}$ applied to grapefruit inoculated with $P$. digitatum provided partial decay control. Surface injuries are generally favorable sites for infection by postharvest decay organisms. However, the heat treatments may have promoted lignin formation and accelerated peel injury healing, which also inhibits fruit rot in grapefruit (Brown et al., 1978). McGuire (1991), however, obtained significantly more decay with $\mathrm{HW}$ than with forced hot air.

The overall mean for aging was $6 \%$ after 5 weeks' storage. However, the difference in aging between AA (10\%) and VH-treated $(1 \%)$ fruit is unexplained. The differences in the incidence of aging among treatments in this study are not consistent with previous findings by Miller and McDonald (1991) where VH-treated and control fruit aged similarly. In our current study, $\mathrm{VH}$-treated fruit had $\approx 12 \%$ serious scald compared with $<1 \%$ in a previous study (Miller et al., 1991). McGuire (1991) compared forced hot air (no free moisture on fruit during treatment) at $48{ }^{\circ} \mathrm{C}$ with $\mathrm{HW}$ to grapefruit, with gradually increasing or with constant temperature for similar target temperatures. He found excessive peel injury after subsequent storage such that fruit marketing would be hindered. McGuire treated fruit until core temperatures reached 45.6 or $46.3{ }^{\circ} \mathrm{C}$, which was higher than the sufficient core temperatures of $43.5^{\circ} \mathrm{C}(50 \mathrm{~min})$ to control the $\mathrm{CFF}$. He reported excessive decay $(\approx 50 \%)$ following hot water immersion treatment, whereas, in our current study decay was decreased by heat treatments. The seriousness of peel disorder and decay in grapefruit following these heat treatments may be seasonal in nature and likely related to preharvest cultural factors, such as rootstock, production practices, or climatic conditions during physiological development of fruit (Grierson and Ben-Yehoshua, 1986; Reitz and Embleton, 1986).

Table 2. Peel color and pulp texture preference values for preharvest gibberellic acid (GA) treated grapefruit following ambient air (AA), ambient water (AW), vapor heat $(\mathrm{VH})$, or hot water $(\mathrm{HW})$ and storage for 4 weeks at $10^{\circ} \mathrm{C}$ plus 1 additional week at $20^{\circ} \mathrm{C}$.

\begin{tabular}{|c|c|c|c|c|c|}
\hline \multirow{2}{*}{ Variable } & & \multicolumn{3}{|c|}{ Color values } & \multirow{2}{*}{$\begin{array}{c}\text { Pulp } \\
\text { texture }\end{array}$} \\
\hline & & $\mathrm{L}^{*}$ & $\mathrm{a}^{*}$ & $b^{*}$ & \\
\hline \multicolumn{6}{|l|}{$\overline{\mathrm{GA}}$} \\
\hline - & & 78.4 & -3.0 & 56.5 & 76.4 \\
\hline+ & & 76.6 & -3.5 & 55.8 & 76.3 \\
\hline \multicolumn{6}{|l|}{ Treatment (T) } \\
\hline $\mathrm{AA}$ & & 76.7 & -4.1 & 56.2 & 75.8 \\
\hline $\mathrm{AW}$ & & 76.7 & -4.0 & 55.2 & 78.6 \\
\hline VH & & 76.4 & -2.3 & 55.5 & 77.7 \\
\hline HW & & 76.7 & -3.1 & 56.0 & 73.3 \\
\hline Factor & df & \multicolumn{4}{|c|}{ Mean squares } \\
\hline GA & 1 & $58.5^{*}$ & $3.1^{*}$ & $8.3^{\mathrm{Ns}}$ & $0.08^{\mathrm{Ns}}$ \\
\hline $\mathrm{T}$ & 3 & $0.5^{\mathrm{ss}}$ & $8.1^{*}$ & $1.1^{\mathrm{Ns}}$ & $100.0^{*}$ \\
\hline $\mathrm{GA} \times \mathrm{T}$ & 14 & $0.5^{\mathrm{ss}}$ & $0.2^{\mathrm{Ns}}$ & $3.9^{\mathrm{ss}}$ & $175.0^{*}$ \\
\hline Error & & 1.2 & 0.4 & 2.4 & 0.0 \\
\hline
\end{tabular}

Ns, ${ }^{*}$ Nonsignificant or significant at $P \leq 0.05$ by analysis of variance procedures.

\section{Conclusion}

VH treatment is approved, and the HW treatment may, in the future, be approved for use on grapefruit in the United States. Heat treatments may, however, induce peel injury during posttreatment storage. This study indicates that grapefruit is likely near the threshold for damage during heat treatments at the time/ temperature regimes found effective for control of the CFF; therefore, shippers must determine whether grapefruit from their particular production area will withstand the stress of heat treatment before large scale commercial application. VH and HW treatment of 'Marsh' grapefruit should only be considered by Florida grower/shippers in the absence of less stressful quarantine treatments.

\section{Literature Cited}

Brown, G.E., M.A. Ismail, and C.R. Barmore. 1978. Lignification of injuries to citrus fruit and susceptibility to green mold. Proc. Fla. State Hort. Soc. 91:124-126.

Brown, G.E., W.R. Miller, and R.E. McDonald. 1991. Control of green mold in 'Marsh' grapefruit with vapor heat quarantine treatment. Proc. Fla. State Hort Soc. 104:115-117.

Gaffney, J.J. and J.W. Armstrong. 1990. High-temperature forced-air research facility for heating fruits for insect quarantine treatments. J. Econ. Entomol. 83:1959-1964

Greany, P.D., R.E. McDonald, W.J. Schroeder, P.E. Shaw, M. Aluja, and A. Malavasi. 1995. Use of gibberellic acid to reduce citrus fruit susceptibility to fruit flies, $\mathrm{p}$ 40-48. In: P.A. Hedin (ed.). Bioregulators for crop protection and pest control. Amer. Chem. Soc., Washington, D.C.

Grierson, W. and S. Ben-Yehoshua. 1986. Storage of citrus fruit, p. 479-505. In: W. Wardowski, S. Nagy, and W. Grierson. (eds.). Fresh citrus fruits. AVI, Westport Conn.

Hallman, G.J., J. Gaffney, and J.L. Sharp. 1990. Vapo heat treatment for grapefruit infested with Caribbean fruit fly (Diptera: Tephretidae). J. Econ. Entomol. 83:1475-1478

Hallman, G.J. and D.S. Chalot. 1993. Possible quarantine treatments for Florida agricultural food commodities. Proc. Fla. State Hort. Soc. 106:240-243.

McDonald, R.E., W R. Miller, T.G. McCollum, and G.E. Brown. 1991. Thiabendazole and Imazalil applied at $53 \mathrm{C}$ reduce chilling injury and decay of grapefruit HortScience 26:397-399.

McGuire, R.G. Market quality of grapefruit after heat quarantine treatments. 1991. HortScience 26:13931395.

Miller, W.R., R.E. McDonald, T.T. Hatton, and M. Ismail 1988. Phytotoxicity to grapefruit exposed to hot wate immersion treatment. Proc. Fla. State Hort. Soc. 101:192-195.

Miller, W.R. and R.E. McDonald. 1991. Quality of stored 'Marsh' and 'Ruby Red' grapefruit after high-temperature, forced-air treatment. HortScience 26:11881191.

Miller, W.R., R.E. McDonald, G. Hallman, and J. Sharp 1991. Condition of Florida grapefruit after exposure to vapor heat quarantine treatment. HortScience 26:4244.

Reitz, H.J. and R.W. Embleton. 1986. Production practices that influence fresh fruit quality, p. 49-75. In: W. Wardowski, S. Nagy, and W. Grierson (eds.). Fresh citrus fruits. AVI, Westport, Conn.

Sharp, J.L. 1985. Submersion of Florida grapefruit in heated water to kill stages of Caribbean fruit fly, Anastrepha suspensa.Proc. Fla. State Hort. Soc. 98:7880.

U.S. Dept. of Agriculture. 1976 (revised 1994). Plant protection and quarantine treatment manual. vol. 2. p 5.50. Animal and Plant Health Inspection Serv., U.S Dept. Agr., Washington, D.C. 